\title{
Distopia e hibridismo em A Nova Ordem, de B. Kucinski
}

\author{
Dystopia and hybridism in A Nova Ordem, by B. Kucinski \\ Fernanda Nunes de ARAÚJO* \\ Universidade Estadual de Goiás (UEG) \\ Paulo Alberto da Silva SALES** \\ Instituto Federal Goiano (IF Goiano)
}

RESUMO: Desenvolve-se uma leitura do romance A Nova Ordem, publicado em 2019, de B. Kucinski, a partir da perspectiva do hibridismo entre fato e ficção. Ao valer-se de elementos da realidade, sobretudo relacionados à sociedade e à política brasileira contemporânea, a ficção de Kucinski se configura por meio de um enredo distópico. Nele, é apresentado uma sociedade apocalíptica, emruínas, permeada por constantes genocídios de grupos nomeados como utopistas, bem como se instauram, em todo o território nacional, práticas de manipulação comportamental dos indivíduos. Nossa leitura se detém, então, a perscrutar a representação da distopia presente na configuração dos generais que comandame da massa que compõea "nova ordem", inviabilizando o direito de sonhar dos brasileiros.

PALAVRAS-CHAVE: Distopia. Hibridismo. A Nova Ordem.

ABSTRACT: A reading of the novel A nova ordem, published in 2019, by B. Kucinski, is developed from the perspective of hybridism between fact and fiction. By drawing on elements from reality specially those related to Brazilian society and politics, Kucinski's fiction configures itself by a dystopic plot. In that, there is presented an apocalyptic society in ruins that is pervaded by frequent genocides of groups named as utopic as well as there are many practices of behavioral

\footnotetext{
* Mestranda em Língua, Literatura e Interculturalidade na Universidade Estadualde Goiás, Campus Cora Cora lina, Cidade de Goiás, Goiás, Brasil. E-mail: fnunesaraujo91@gmail.com

${ }^{* *}$ Professor do Instituto Federal Goiano (IF Goiano), Campus Hidrolândia, Goiás, Bra sil, e do Programa de Pós-Graduação em Língua, Litera tura e Intercultura lidade (POSLLI) da Universida de Estadualde Goiás (UEG), Campus Cora Coralina, Cidade de Goiás, Goiás, Brasil. E-mail: paulo.alberto@ifgoiano.edu.br. Orcid: 0000-0001-9980-2561.
} 
manipulation of the people. Our reading examinate the representation of dystopia in the plot through the configuration of the generals who command the nation and the mass the integrates the new order who, in the end, derail the Brazilians the right to dream.

KEYWORDS: Dystopia. Hybridism. A Nova Ordem.

\section{INTRODUÇÃO}

[...] Qualquer estudo sobre o espírito utópico deve ocupar-se de sua situação atual. [...] Apoia-se em uma leitura do registro histórico - precisamente na leitura dos grandes romances "antiutópicos" tais como 1984 - que é profundamente equivocada. Baseia-se em uma distensão da categoria "utópica", de modo a nela incluir qualquer ideia de sociedade futura, não importando o que isso implique de vicioso ou exclusivista. Todos os ditadores do século XX, de Hitler a Pol Plot, e todos os terroristas do século XXI, foram taxados de utópicos. (JACOBY, 2007,p. 10)

[...] Foram identificados e liquidados os principais formuladores do pensamento crítico e os chefes do Instituto Butantã e de Manguinhos. Diz que os trabalhos da fábrica, em especial a compilação de listas, foram essencia is ao sucesso da operação, o que abre amplos horizontes de trabalho para todos. Nossa tarefa, agora, acrescenta o major, é desbaratar a subversão utopística. Defender o sistema financeiro é um dos objetivos nacionais permanentes da Nova Ordem. (KUCINSKI, 2019, p. 58-59)

Literatura e história são dois campos de pesquisa que dialogam constantemente e que exercem um papel fundamental no desempenho da nossa percepção sobre o passado ao tratarem de assuntos relevantes à sociedade e que mudaram, de alguma forma, o seu rumo tanto nos aspectos socioculturais quanto nos aspectos econômicos-políticos. Assim, a ficção torna-se uma oportunidade de representação de determinados momentos da história, ao servir de aporte para a retomada da memória, dando-lhe espaço para a elaboração de uma narrativa ficcional sem compromisso com a verdadee, portanto, capaz de extravasar com a realidade registrad a ao longo do tempo.

A respeito da retratação, na ficção, de elementos da realidade social e política nacional, podemos destacar a obra ficcional do escritor e jornalista Bernardo Kucinski, conhecido no meio literário como B. Kucinski, cujo projeto literário tem se servido de 
elementos relacionados a fatos históricos, memorialísticos e testemunhais. Seus livros têm registrado em sua trajetória literária uma espécie de "catarse" em relação aos "anos de chumbo" vivenciados pelo Brasil, sobretudo nas referências às décadas de 1960 e 1970, após o golpe militar que implantou um dos mais cruéis sistemas de repressão na história do país. Kucinski traz na memória marcas irreparáveis de violências causadas pelos sistemas ditatoriais, sobretudo ligado aos governos de Garrastazu Médici e Ernesto Geisel. O autor é filho de imigrantes poloneses que perderam grande parte da sua família nos campos nazistas de concentração. Além disso, o escritor também sofreu um grande trauma ao vivenciar, em 1974, o sequestro da sua irmã Ana Rosa Kucinski, professora do departamento de Química da USP e integrante da ALN (Aliança Libertadora Nacional), e que é tida até os dias de hoje como uma desaparecida política. A história de Ana Rosa culminou, em 2011, na escrita do romance $K$ - O relato de uma busca, um de seus livros mais conhecidos e que é considerado, pela crítica literária, como um dos romances contemporâneos mais representativos sobre a ditadura civil-militar brasileira. Traduzida para vários idiomas, essa obra marca a estreia de Kucinski na ficção, possibilitando ao autor participar como finalista de importantes prêmios da literatura nacional e internacional, como é o caso do Prêmio São Paulo de Literatura e do Prêmio Portugal Telecom, ambos no ano de 2012. Em sequência ao romance $K$, Kucinski lança diversos outros trabalhos. A coletânea de contos Você vai voltar para mim é lançada em 2014. No ano seguinte, o romance policial Alice - Não mais que de repente. Em 2016, a novela Os visitantes, que retoma alguns eventos narrados em $K-O$ relato de uma busca. Já em 2017, o autor publica o romance Pretérito Imperfeito. Mais recentemente, em 2019, publica A Nova Ordem, livro, esse, que nos ocuparemos neste artigo ${ }^{1}$.

O romance A Nova Ordem, publicado em 2019, pela editora Alameda, ao mesmo tempo que faz uma analogia a um sistema ditatorial do passado, constrói, também, uma alegoria na qual se vislumbra o cenário social e político atual do Brasil - a partir dos anos 2018 - que elegeu um militar de extrema direita para a presidência da república. Nesse livro, Kucinski se propõe a representar uma ficção distópica em que se percebe a monstruosidade de atos totalitaristas, banalizando o mal na sociedade. É evidenciado a descrença em um mundo sem sonhos, o que abre caminho para a criação de situações

\footnotetext{
${ }^{1}$ Foram publicados, em 2020, o livro Júlia, nos campos conflagrados do senhor, e mais recentemente, em 2021, A cicatriz e outras memórias, que reúne sobre suas formas ficciona is breves.
} 
ilógicas e absurdas. Nessa narrativa, em específico, fica evidenciado o posicionamento político do autor, cujo discurso deixa evidente sua ideologia contrária aos regimes ditatoriais e totalitários. Na última página do romance, em que se encontram os créditos da editora, o escritor afirma: "esta obra foi impressa em São Paulo em 2019, primeiro ano do governo do presidente Jair Bolsonaro, apologista da Ditadura Militar Brasileira" (KUCINSKI, 2019, p. 180).

No que diz respeito ao seu percurso político-social, verifica-se que ele foi militante estudantil, jornalista e ativista político contrário ao sistema ditatorial militar e, foi, por sua vez, perseguido e exilado. Ao retornar ao Brasil, Kucinski atuou aind a como professor da USP e no período de 2003 a 2006 assumiu a função de Assessor Especial da Secretaria de Comunicação Social (SECOM), da Presidência da República, após ser convidado pelo então presidente, Luiz Inácio Lula da Silva, eleito à época pelo Partido do Trabalhadores (PT).

Todo esse arcabouço político-ideológico, somado à imaginação, à memória e à habilidade literária de Kucinski vão se entrelaçar nessa narrativa ficcional que contribuirá para a formação identitária das personagens de A Nova Ordem. Há indivíduos que representam várias classes de brasileiros, sobreviventes das atrocidades impostas por governos e sistemas ditatoriais. Nesse sentido, objetiva-se refletir aqui sobre a configuração dessa narrativa que se apresenta como uma distopia, com algumas especificidades relacionadas à política e à história do Brasil. Nela, constata-se um hibridismo de dicções que, embora projetem um futuro apocalíptico, entrelaçam-se referências histórico-sociais recentes e da atual gestão presidencial.

Sabendo-se que a produção ficcional contemporânea pode ser observada em suas diversas formas de ocorrências, para analisarmos as confluências entre o real e o ficcional e a performance da escrita de Kucinski, recorreremos ao seguinte corpus teórico: Russell Jacoby (2007), Florencia Guarramuño (2014), Jean François Lyotard (2021), Zênia de Faria (2012) Leyla Perrone-Moisés (2016) e Hannah Arendt (2012). Destacamos, de antemão, que a produção ficcional de Kucinski extravasa sentimentos resguardados por uma espécie de anomia social que, há tempos, tem invadido o Brasil e o mundo.

\section{Ficção distópica: um reflexo do caos}


A escrita de ficções distópicas tornou-se comum a partir do início do século XX por rememorar momentos de tensões e de injustiças em que os regimes políticos de grande parte do mundo apostavam no ordenamento do Estado, impondo sobre a população uma espécie de submissão diante da opressão daqueles que detinham o poder. A desilusão recorrente deste contexto de medo e de barbárie foi impressa em obras de ficção e ganharam espaço na literatura e nos cinemas com suas narrativas "proféticas" que têm suscitado a reflexão da sociedade por meio do assombro e do caos como reflexo do futuro. Tais cenários são retratados nos grandes romances distópicos de língua inglesa do século XX, principalmente em 1984, de George Orwell (2009), Admirável mundo novo, de Aldous Huxley (2014) e Fahrenheit 451, de Ray Bradbury (2020). A esse respeito, Pavloski entende que

\footnotetext{
O futuro, a o potencia lizar-se como uma incógnita diante de um novo período histórico, suscita a reflexão sobre os caminhos pelos quais as sociedades podem se desenvolver. Nesse sentido, os textos utópicos e distópicos são resgatados e valorizados muito menos pelos seus respectivos graus de otimismo e pessimismo do que pela sua capacidade analítica dos elementos que compõem a realidade $(2005$, p. 7)
}

De forma expressiva, nota-se, no século XXI, um aumento considerável da escrita de romances distópicos e do seu consumo que tem atingido, cada vez mais, um público específico formado por leitores críticos que não se identificam com "finais felizes", resultantes de um mundo utópico e que, de certa forma, demonstram sua preocupação com o futuro da humanidade. De acordo com Bakhtin (1988, p. 400), o romance nos permite refletir, "mais profundamente, mais substancialmente, mais sensivelmente e mais rapidamente a evolução da própria realidade", o que justificaria a escolha do gênero.

Essa relação do público com as obras distópicas pode ser explicada pelo momento desord enado pelo qual o mundo atravessa e onde os extremos se entrecruzam e se chocam, causando prejuízos imensuráveis à humanidade. Neste sentido, o desejo otimista de um lugar ideal, choca-se com o pessimismo causado pela dualidade de elementos como: a miséria e a riqueza; o Estado e o povo; o capitalismo e o humanismo, as grandes metrópoles e o bucólico. A literatura torna-se, então, um espaço de reflexão sobre o sofrimento humano que é justificado pela falta de liberdade, pela estratificação humana, 
pelas desigualdades sociais, pelas condições ambientais adversas, pela "invasão" dos sitemas digitais, e pelo desrespeito à individualidade e à coletividade dos cidadãos.

Cabe à ficção distópica, nessa perspectiva desencantada com a realidade, narrar e anunciar, de forma catastrófica, as possíveis consequências da desumanização destes elementos, cujos responsáveis são inimigos invisíveis escondidos por toda parte. A denúncia de uma sociedade indesejada, submetida à manipulação de um Estado autoritário que mais se preocupa com a economia do que a vida humana compõe as páginas das obras distópicas escritas a partir do século XX. No seu estudo Imagem imperfeita: pensamento utópico para uma época antiutópica, Russell Jacoby (2007, p. 25) entende que

\footnotetext{
toda generalização é falsa. Vivemos em uma época de esperança e transformação. Ta mbém vivemos em uma época de resignação, rotina e talvez alarme. Prevemos que o mundo vai melhorar, tememos que ele piore. Existimos em meio a inacreditavelmente ricos e a uma pobreza paralisante. Conduzimos nossas vidas em paz e somos cercados pela violência. Os ricos, em condomínios espaçosos, preocupam-se em manter seus carros esportivos sem arranhões. Os pobres, em guetos imundos, sonham com água limpa, enquanto os refugiados das infindas guerras civis, com quatro paredes e um teto. (JACOBY, 2007, p. 25).
}

Diante desta perplexa relação do sujeito, que se vê entre o desejo de um lugar melhor e a descrença que prevê dias piores, a literatura contemporânea encontrou na distopia um caminho importante para a construção de narrativas ficcionais que extravasam com o mundo real sem se desvincular dele, e nas quais o escritor parece atravessar os seus leitores, fazendo-os refletir de forma crítica e questionadora sobre os rumos que as sociedades têm tomado, a fim de alertá-los sobre os perigos causados, principalmente, pelos grandes avanços tecnológicos e pelas relações de poder que assolam a humanidade. É preciso compreender que a distopia não é o reflexo mecânico da sociedade atual e, sim, uma escrita que mergulha mais profunda e artisticamente na realidade social (que servirá de elemento para a constituição estrutural do texto), e a partir dela produzirá de forma subjetiva e experimental, narrativas literárias baseadas nas experiências e nas problemáticas da contemporaneidade. Ou seja, 
a tarefa da distopia literária, então, é a lertar-nos e educar-nos sobre as distopias da vida real. Não precisa fornecer um final feliz para fazê-lo: o pessimismo tem seu lugar. Mas pode conceber soluções racionais e coletivas, lá onde florescem a irraciona lidade e o pânico. Oentretenimento desempenha um papel neste processo. Mas a tarefa em questão é séria. Ganha importância diariamente. Aqui, então, está um gênero e um conceito cuja hora chegou. Que ele floresça! (CLAYES, 2017,p. 501)

Desta forma, fica claro que não há na ficção distópica nenhuma pretensão de buscar respostas, ou mesmo, o compromisso de trazer soluções para qualquer que sejam os questionamentos dos seus interlocutores, mesmo que haja uma mescla entre a ficção e a realidade, haverá um espaço específico para que o leitor possa transitar entre o real e o ilusório. Neste sentido, Tânia Pellegrini (2009), em seu artigo intitulado Realismo: $a$ persistência de um mundo hostil, explica que, de modo geral,

\footnotetext{
os "realistas clássicos" procuram adquirir primeiro uma competência específica em relação à matéria selecionada, para depois criar a partir de um acúmulo de informações. Contudo, não renunciam ao ato ficcional propriamente dito, pois sabem que o texto realista não copia o real, mas pretende fazer crer que remete a uma realidade verificável. Daí a ideia de ilusão, de mentira, que se perpetuou, pois existe um sujeito, um olhar que enquadra, recorta, organiza, confere um sentido àquilo que se observa e documenta, ainda como desordem e ausência de significa dos. (2009, p.16)
}

No entanto, o texto distópico, que aqui o entendemos como fruto do hibridismo entre realidade e ficção, se propõe a causar uma espécie de inquietude no leitor através da sua configuração estética, dando-lhe espaço para que seja despertado o espírito observador e crítico de acordo com as experiências externas daquele que lê. E é isso que o autor imprime em sua literatura: um caráter crítico e, muitas vezes, satírico, abrindo espaço para que o leitor possa se deleitar, contemplando a leitura e dela se apoderar de acordo com suas expectativas e interpretações.

Para compreendermos melhor sobre o que é a distopia, partiremos da teorização sobre utopia, já que dela deriva o termo em questão que tem sua etimologia no grego e significa: "dys" "mau, ruim" + "topos" "lugar". No estudo Um presente para o futuro: a 
distopia contemporânea e suas interseções com a experiência pós-moderna (2019), Millena Cristina Silva Portela e Maria Aracy Bonfim Serra Pinto afirmam que

\begin{abstract}
diversas vezes, é no ideal utópico que as primeiras sementes da distopia são plantadas; o cenário utópico requer domínio o controle para que chegue a o seu fim harmônico, assim ilhas paradisíacas são "civilizadas", povos "bárbaros" são colonizados, um sistema governamentalé implementado, limites espaciais são impostos. A utopia de alguns normalmente será a distopia de outrem. (PORTELA; PINTO, 2019, p. 125)
\end{abstract}

Assim, embora boa parte das teorias afirmem que a distopia é o oposto da utopia, nos deteremos em analisar a semelhança entre elas e em que momento elas se intercruzam e se distanciam. Pavloski (2005) defende que o futuro, ao potencializar-se como uma incógnita diante de um novo período histórico, suscita a reflexão sobre os caminhos pelos quais as sociedades podem se desenvolver. Nesse sentido, os textos utópicos e distópicos são resgatados e valorizados muito menos pelos seus respectivos graus de otimismo e pessimismo do que pela sua capacidade analítica doselementos que compõem a realidade. Dessa forma, as utopias e as distopias acionam aspectos do imaginário humano que funcionam simultaneamente como crítica do tempo presente e projeção das possibilidades futuras.

Observa-se, portanto, que as semelhanças entre utopia e distopia vão além da etimologia e estão diretamente relacionad as entre si, já que partimos de um ideal utópico, que almeja a construção de uma sociedade ideal, onde todos pudessem conviver em harmonia. Porém, para que essa vivência se concretizasse seria preciso que o Estado administrasse esse mesmo lugar impond o um sistema convencional que limitaria ações e comportamentos que garantissem o bem comum, ou seja, um estado aliado do seu povo.

Assim, a utopia retoma a sua etimologia ${ }^{2}$ (ou=não) topos (lugar), ou seja, o não lugar, o lugar imaginável, porém, inatingível. Por um lado, o otimismo dos que sonham, por outro, o pessimismo dos que não acreditam. Percebe-se, aqui, uma linha muito tênue entre utopia e distopia que talvez possa ser explicada se tomarmos como princípio que uma ideia precede a outra e que ambas analisam a sociedade atual a fim de representá-la como imagem do futuro. Porém, a distopia, ao contrário da utopia, vai retratar esse futuro

\footnotetext{
${ }^{2}$ Segundo o Dicionário Houaiss da Língua Portuguesa.
} 
a partir de um olhar derrotista, projetando um futuro absurdo e trágico como resposta às atitudes e aos comportamentos humanos. Neste sentido, Leyla Perrone-Moisés apontaque

\begin{abstract}
as utopias que se consideravam terminadas são as da modernidade: as que se basea vam no progresso, na revolução, no advento de um futuro de justiça social e pazentre as nações. De fato, neste início de século XXI, esses objetivos não se concretizam. Nenhuma das ideologias políticas evitou que o mundo continuasse em guerra, muito pelo contrário. O progresso tecnológico foi posto a serviço da matança, tanto nos exércitos das nações democráticas qua nto nas ações terroristas dos que a elas se opõem. (2016, p. 221)
\end{abstract}

A frustração e a desesperança ao não ver concretizar-se as utopias de outrora e a constatação de que nenhuma das primícias idealizadas foram capazes de livrar-nos das ganâncias e das injustiças devassadas num contexto de acelerada transformação, tem levado os escritores a buscarem nas ficções distópicas um caminho para, deforma irônica e satírica, alertar os leitores sobre a possibilidade de futuros catastróficos. De fato, a distopia é uma narrativa de assombro na qual nada é questionado e nem previsível. Para Isaiah Berlin (1991), as ficções distópicas contradizem as generalizações propostas pelos utopistas e

\footnotetext{
pintam um quadro horripilante de uma sociedade sem atritos em que as diferenças entre os seres humanos são, tanto quanto possível, eliminadas, ou pelo menos reduzidas, e o padrão multicolorido dos vários temperamentos, inclinações e ideais humanos - em suma, o próprio fluxo da vida - é brutalmente reduzido à uniformidade, aprisionado em uma camisa-de-força social e política que fere e estropia, terminando por esmagar os homens em nome de uma teoria monística, do sonho de uma ordem perfeita e estática (BERLIN, 1991, p. 48-49).
}

Logo, as ficções distópicas utilizam-se da sátira e da ironia para denunciar comportamentos e atitudes que ameaçam a liberdade, a individualidade, a convivência coletiva de um povo e visa uma hegemonia em relação ao poder. Nesse sentido, 
apresentaremos, a seguir, a configuração distópica presente no enredo d'A Nova Ordem, de Kucinski.

\section{Elementos do gênero distópico em A Nova Ordem}

Com a implantação da Nova Ordem no Brasil, Kucinski constrói um cenário de horrores no momento atual do país. Composta por vinte e dois capítulos, a narrativa se vale de um narrad or heterodiegético e com focalização onisciente intencionais, uma vez que as atrocidades narradas têm o compromisso de causar uma sensação de um realismo indesejável. A Nova Ordem, como o nome já impõe, é regida pelo governo militar alusão aos vinte e um anos de regime ditatorial no Brasil bem como à extrema inclinação do atual governo do presidente Jair Bolsonaro a atos antidemocráticos e inconstitucionais - na pessoa do General Lindoso Fagundes, que tem como ídolos os ditadores Pinochet e Stalin, uma vez que "[...] cada um a seu modo exerceu o poder supremo, o de ditar quem pode viver e quem deve morrer" (KUCINSKI, 2019, p. 64).

Essa Nova Ordem é gerida por sucessivos éditos que instauram um verdadeiro regime totalitário por parte dos militares. Esses éditos, com base num esquema lógico e não legal, imprimem o terror à população que se encontra aprisionada, isolada e desprovida de laços sociais, atitude previsível de um governo que age em favor dacaptura, não só do cidadão, mas também, do indivíduo, como forma de facilitar o domínio em massa. Foram destituídos quase todos os ministérios: da educação, da cultura, de ciência e tecnologia, do turismo, dentre vários outros, bem como foram revogadas várias leis conquistadas há vários anos, tais como leis de incentivo à cultura, leis de diretrizes e bases da educação, cotas raciais, etc. Todos os éditos são datados de 2019. O primeiro deles é impactante. Trata-se da extinção do ministério do trabalho:

\footnotetext{
As cooperativas foram fechadas pelo primeiro ato jurídico da Nova Ordem, o Édito 01/2019, de enorme abrangência, que dispõe sobre a Produtividade do Trabalho. Seu artigo primeiro extingue o Ministério do Trabalho e Emprego, a Secretaria de Inspeção do Trabalho, a Secretaria Nacional de Economia Solidária, o Programa Nacional de Erradicação do Trabalho Escravo (PETE), o Programa Nacional de Erradicação do Trabalho Infantil (PETI) o DIEESE e O DIESAT e o Fundo de Amparo ao Trabalhador; o artigo 2 extingue a Justiça do Trabalho e determina o arquivamento dos processos em curso; o artigo 3
} 
declara a caducidade das Leis Trabalhistas, do Estatuto da Empregada Doméstica, do Estatuto do Trabalhador Rurale da Lei do Salário Mínimo; o artigo 4 revoga a estabilidade no emprego do funcionário público; o artigo 5 revoga o capítulo 149 do código penalque punia o trabalho escravo; o artigo 6 abole as a ssociações de servidores públicos, os sindica tos operários e rurais, as cooperativas habitacionais, de crédito e de trabalho, as associações de pesca dores e de artesãos, as comissões de fábrica, os clubes de cabos, sargentos e marinheiros, assim como qualquer forma de associação de trabalhadores, artesãos ou militares subalternos; o artigo 7 revoga a Lei 8213/91 que obrigava empresas com 100 ou mais funcionários a preencher de dois a cinco por cento dos seus cargos com pessoas portadoras de deficiência; o artigo 8 cria na Polícia Federal a Delegacia Especializada de Fiscalização da Produtividade do Trabalho; o artigo 9 enquadra infratores na Lei Antiterrorismo (Lei 13.260/2016). (KUCINSKI, 2019,p. 26-27)

Além dos éditos que retiram todos os direitos adquiridos em anos de luta e trabalho, as cenas narradas em A Nova Ordem apresentam uma sociedade apática, condicionada a sobreviver e sofrer num ambiente cheio de mentiras e de manipulações comportamentais. Já primeiras linhas, a voz narrativa configura os chefes de estado do Brasil que censuram, torturam e assassinam aqueles que ousam desafiá-los. No primeiro capítulo intitulado "A Nova Ordem proclama seu advento. O fechamento das universidades e a morte do pensamento crítico", instaura-se o horror com o qual o leitor irá se deparar por todo o enredo:

Anoitece. Pelas vidraças esburacadas, amplas e inalcançáveis, chega do mar uma brisa refrescante. Os cientistas formam pequenos grupos dispersos no vasto galpão. Antes das privatizações, a li funciona va o almoxarifado do maior estaleiro nacional. Tufos de musgo nos cantos e teias de aranha nas traves denunciam o abandono. No piso de cimento, misturam-se a reia, folhas secas e pontas de cigarro.

Junto à entrada, um grupo mais numeroso a glomera-se como que à espera de um anúncio importante. Os demais, aos poucos, vão se sentando no cimentado. Não se vê nenhuma mulher. Apesar do desconforto, discutem animadamente, alguns por reencontra rem antigos colegas, outros, envaidecidos por constarem 
na lista dos mais importantes cientistas do país, segundo um deles ouvira do tenente que o prendera.

(KUCINSKI, 2019,p. 9)

A ambientação opaca, cinza e mórbida é apresentada no primeiro parágrafo desse capítulo, em que se encontram capturados pelos generais todos os "utopistas", ou seja, os portadores de senso crítico e, portanto, subversivos à Nova Ordem. Médicos, advogados, professores, reitores, escritores, artistas e diversos outros intelectuais se encontram presos em uma espécie de galpão sem condições mínimas de subsistência. Mais tarde, todos serão fuzilados e enterrados. À essa operação de extermínio dos utopistas, os generais a intitularam como "Operação Cátedra”.

Nos capítulos seguintes, a voz narrativa ficcional projeta uma sociedade que não consegue desvencilhar-se das experiências passad as de um período desolador que insiste em arraigar o país, bem como não há qualquer perspectiva de melhoria e/ou de projeções otimistas para o futuro. Observe um trecho da obra que certifica a opressão e o autoritarismo dos governantes:

\footnotetext{
Noite avançada, o grande portão é outra vez aberto e surge um oficial com patente de coronel, acompanhado de dois soldados. Um deles traz um estrado e o deposita no centro da entrada. O coronel sobe no estrado de mão esquerda na cintura. A direita empunha uma pistola. Os cientistas agrupam-se à sua frente, curiosos. O coronel fal em tom de comando: - Quando eu descer deste estrado, os senhores vão caminhar ordeiramente, até onde lhes será indicado pelos soldados. (KUCINSKI, 2019, p. 17-18).
}

Na nova ordem, as pessoas deixaram de almejar uma vida igualitária e harmônica, tendo em vista que houve o silenciamento de vários grupos sociais, tais os cientistas, pensadores e pesquisadores - denominados utopistas - bem como todos os outros sujeitos indesejáveis à Nova Ordem. Ressalte-se que a estratégia secreta da Nova Ordem era reduzir a população brasileira. Pelo menos, 90 milhões de vidas seriam perdidas para que os propósitos mercadológicos e neoliberais dos militares tivessem êxito.

A alienação coletiva, presente no romance, é uma das principais características das ficções distópicas e a razão propulsora para a sátira da maioria dos escritores deste 
movimento. Em 1984, Orwell satiriza, ao apresentar o Ministério da verdade ou Miniver, cuja função era “ocupar-se das notícias, diversões, instrução e belas-artes” (2009, p. 10). Também ironiza ao utilizar da tecnologia, na qual a presença de uma teletela tem a função de vigiar todas as ações dos indivíduos.

Essa relação ao uso da tecnologia com o monitoramento do indivíduo, Kucinski cria a personagem Ariovaldo - um capitão médico psiquiatra, que mais tarde se tornaria tenente-coronel pelos seus feitos -, a desenvolver projetos e ferramentas científicas, cujos mecanismos levam a extração do pensamento e atitudes de "rebeldia" das mentes humanas a fim de que se possa manter a "ordem" e o controle social na sociedade. Essa personagem, um médico-militar a serviço da nova ordem, é totalmente obcecado pela psiquiatria e será o principal responsável

pelo extermínio dos cidadãos que fazem parte do movimento utópico. Ariovaldo é a mais fiel representação de usurpadores da sociedade que se beneficia das suas relações de poder para agir a favor dum regime político corrupto, violento e antidemocrático ao qual está vinculado.

Kucinski, assim como Orwell, utiliza da ironia criando estratégias narrativas para demonstrar como a tecnologia pode ser invasiva quando, aliada ao Estado, se propõe a furtar a subjetividade das pessoas e manipular o comportamento humano e social, a fim de intervir nas decisões. Como se sabe, os séculos XX e XXI têm sido marcados pelos acelerados avanços tecnológicos, cujas implicações têm sido aclamadas pelos governos, pelas esferas empresariais, pela imprensa e pela população em geral por trazer possibilidades nunca antes imaginadas. Por outro lado, enfrenta-se um conflito das relações humanas que, muitas vezes, beira à barbárie. Neste sentido, essa dualidade, alimentada pelo capitalismo, gera uma sensação de instabilidade, sem que haja previsão de onde isso tudo poderá nos levar. Jacoby (2007, p. 218) alerta que

\footnotetext{
o mundo não sofre apenas com guerras desumanas, mas ta mbém com um meio a mbiente degra da do, serviços médicos limitados, desemprego e a ssim por diante. Hoje essa crise parece insolúvel, mas essa é uma observação política, não técnica.Temos meio de produzir automóveis eficientes com acessórios luxuosos, podemos colocar um veículo de alta tecnologia, que se move com precisão, em Marte, mas não conseguimos reunir a vontade ou os recursos para corrigir uma ordem social defeituosa. As consequências humanas desse fracasso - muitos deixados para trás e muitos prejudicados - fazem com que, os que têm sorte, se
} 
escondam atrás de seus altos portões. Esse não é o único caminho. É possível, e a té mesmo necessário, tomar parte nas questões urgentes do dia-a-dia enquanto se mantém um ouvido, para não dizer um olho, no futuro.

Essa imprecisão em relação ao futuro tem sido acelerada no ritmo da revolução tecnológica e, de certa forma, afetando a sociedade contemporânea e colocado cada vez mais em risco a preservação da sua identid ade, bem como suprimindo a sua subjetividade. Foucault (2018, p. 168), chama a atenção sobre "os olhares que devem ver sem ser vistos" e que funcionam como uma espécie de vigilância em surdina, cuja intenção é captar informações dos sujeitos, a fim de utilizá-las a favor das instituições de poder, quando se fizer necessário.

N'A Nova Ordem, um dos audaciosos projetos do capitão médico Ariovaldo é, com a ajuda da tecnologia, criar um capacete neuro-sensorial para identificar o setor da massa cerebral e ter acesso aos pensamentos e aos sentimentos dos seres humanos. Assim, o narrador, de forma dialógica, evidencia uma forte intenção dos militares em manipular a massa a fim de manter o controle do Estado. Essa afirmação pode ser confirmada na passagem a seguir, que descreve detalhes de um outro projeto de Ariovaldo:

\footnotetext{
Ariovaldo quer chegar a um método que assegura, com a mais absoluta certeza, que o preso falou tudo o que sabe, seja qual for sua estrutura mentale psíquico. Um método científico que extraia da memória do preso todas as informações ali armazenadas para a prática da subversão e da contestação da Nova Ordem, sem depender da vontade ou da determinação do próprio preso. (KUCINSKI, 2019, p. 113)
}

O preconceito e o repúdio ao conhecimento são tendências dos governos totalitários que veem na leitura uma ameaça contra a alienação das massas. Em Fahrenheit 451, Ray Bradbury (2020) apresenta uma sociedade, simbolicamente, "em chamas" que desloca os bombeiros de sua função primordial e dá a eles a responsabilidade de atear fogo aos livros. Lançado em 1953, a obra, cujo título é o indicativo da temperatura ideal para se queimar papel, $451^{\circ}$ Fahrenheit, remete aos espetáculos produzidos pelo governo nazista que reunia multidões em praça pública para verem as queimas de livros. 
Essa transgressão do Estado, que consiste em proibir a posse de livros e aniquilar, de uma vez por todas, esta poderosíssima fonte do conhecimento, está presente também em A Nova Ordem e pode ser percebida através da implantação do édito 13/2019:

\footnotetext{
Trata-se do Édito 13/2019 da Nova Ordem do Impresso que cria o Departamento de Preservação dos Valores da Nova Ordem (DEPREVANO) e proíbe a produção, venda e circulação de publicações não aprovadas pelo DEPREVANO. O édito dá prazo de 60 dias para que pessoas e instituições se desfaçam dos impressos produzidos antes, excetuando-se exemplares da Bíblia Sagrada; seu artigo 3 extingue a Fundação Biblioteca Nacional e demais bibliotecas públicas, o artigo 4 dá prazo de 30 dias para gráficas e copiadoras se cadastrarem no DEPREVANO. (KUCINSKI, 2019, p. 23)
}

Os éditos, no entanto, são análogos aos Atos Constitucionais do período da ditadura civil-militar no Brasil e aparecem na obra, compond o uma narrativa paralela em notas de rodapé. Consistem em impor verticalmente normas de controle e coerção social que manipulam todos os segmentos da sociedade com um discurso autoritário e buscam extinguir de vez qualquer movimento que valorize a educação, a cultura e as artes, entre outros. Essa estratégia literária utilizada pelo autor, soa como um alerta às imposições percebidas já no início do governo que compõem o atual cenário político brasileiro. $\mathrm{O}$ espectro de comportamentos e atitudes já assistidos no Brasil de outrora, ameaçam a paz e a liberdade de um país, colocand o em risco o futuro da democracia, ceifando assim, todas as oportunidades de conhecimento tão necessários para a autonomia e o desenvolvimento de um país.

Assim como Kucinski, Ignácio de Loyola Brandão encontrou na distopia um universo ideal para a projeção de expectativas assombrosas para o futuro, baseando-se num contexto social e político problemático, contaminado por um sistema neoliberal guiado pelo capitalismo. Em sua obra mais recente Desta terra nada vai sobrar a não ser o vento que sopra sobre ela, publicada em 2018 pela editora Global, o narrador, já no I capítulo, anuncia a passagem de um comboio de mortos e informa que em função da travessia, o trânsito deverá ser interrompido por alguns minutos. Esse trecho chama atenção por percebermos que algo tão aterrorizante parece corriqueiro na vida daquela população que não se sensibiliza com tal informação. Observe-se: 
Em três minutos circulará o expresso Corruptela Pestífera. Aconselhamos a fecharem hermeticamente os vidros de seus veículos. O governo não se responsabiliza por contaminações. Em seguida, aguardem com calma e em ordem o comboio dos mortos. (BRANDÃO, 2018,p. 19)

A sistematização da violência e a normatização do absurdo paira sobre as ficções distópicas como uma fuga da realidade por parte da população e como uma forma covarde de aceitar as imposições do Estado. Arendt alerta que, o que caracteriza a propaganda totalitária melhor do que as ameaças diretas e os crimes contra indivíduos é o uso de insinuações indiretas, veladas e ameaçadoras contra todos os que não derem ouvidos aos seus ensinamentos, seguidas de assassinato em massa perpetrado igualmente contra “culpados" e "inocentes" (2012, p. 477-478). Neste sentido, a menção à passagem do comboio de mortos no texto de Loyola tem um cunho irônico, como se fosse uma maneira de anunciar os perigos que estão intrínsecos nestas ações. Situações parecidas estão presentes também em A Nova Ordem e permeiam toda narrativa sob a figura caricata de Ariovaldo, cuja obsessão, se configura na criação dos seus abomináveis projetos científicos e nos seus protocolos de crueldade:

Ariovaldo antecipa a volta para casa. [...] Atra vessa a noite imerso no protocolo de interrogatórios, que chama de plano Alfa. Haverá etapas bem demarcadas. Esgotada uma sem sucesso, passa-se à seguinte. Cada etapa terá um nível definido de suplício e se dará em sala própria. O preso receberá a explicação detalhada das etapas acompanhada de projeções de suplícios, gravados em interrogatórios anteriores. Conhecerá de antemão o horror que o espera se não falar. Só a ssim se instila o medo, pré-condição para o reflexo condicionado. Usar o pavor ao suplício, mais do que o próprio suplício, essa é a filosofia do protocolo. Se após a exposição dos horrores o preso não falar, iniciam-se as etapas propriamente. Na primeira, receberá uma injeção do soro da verdade. Se revelar tudo que sabe será premiado com o fim das etapas, transferência para a cadeia e processo judicial. Se não falar, em punição em vez de premiação, passagem para a etapa seguinte: o choque nas genitais. Na etapa três, o estupro se for mulher, empalação se for homem. Na quarta, o suplício de familiares. A execução simula da se drá na quinta e última etapa (KUCINSKI, 2019, p. 73 -74). 
A banalidade e o desrespeito à vida também estão presentes em A Nova Ordem, quando os militares se reúnem para decidir o que fazer com cerca de dez mil prisioneiros, que segundo eles, não podem continuar vivos por questões de logística e de segurança:

\begin{abstract}
Capitão Gonçalves, apresente o plano. Um oficial jovem, de arma da cavalaria, sobe ao pódio. - Os americanos nos ofereceram a Ricina, é uma dioxina poderosa, bastam 3 miligramas para matar um adulto. E não há riscos de manipulação, a o contrário do polônio e do antrax, que ta mbém foram cogitados. Mas nos faltam instalações a dequadas para dar fim a os corpos. A alternativa mais prática, discreta e barata é o mar. Nem é preciso envenenar, basta anestesiar. Ainda temos as instruções recebidas dos chilenos nos idos gloriosos, mas era preciso testar em águas brasileiras. Fizemos o teste com seis corpos, leves e pesados. Largados a 300 milhas náuticas da costa do nosso litoral Sul. A partir do Paraná, nenhum retornou ao continente. Amarraremos um lastro em cada corpo para impedir que flutuem e sejam avistados por alguma embarcaçao.
\end{abstract} (KUCINSKI, 2019,p. 65-66)

Todo o planejamento de execução é exposto sem nenhuma demonstração de pena ou arrependimento. É tudo minuciosamente pensado e arquitetado para que não corram o risco de que o plano fracasse. Segundo Jacoby (2007, p. 46), ao relacionar iniciativas o genocídio à iniciativas utópicas, esclarece que "atribuir assassinatos em massa aos esforços utópicos é um concenso". Neste sentido, toda essa movimentação em nome do extermínio, rende uma sátira por parte do autor que ao perceber uma visão utópica por parte de governos ditadores e extremistas, vê perpetuar aqueles que, de alguma forma, tragam contribuições ao Estado.

\title{
Considerações finais
}

Evidencia-se que A Nova Ordem amalgama temas relacionados à história, à política e à sociedade brasileira e, ao mesmo tempo, dialoga com as memórias do autor que é performatizada no enredo como uma espécie de catarse. Tais núcleos sugerem uma conexão entre os traumas do passado, a problemática social e política que tem se repetido na atualidade, e que poderá ecoar como perspectivas de um futuro catastrófico. Como artifício da própria narrativa, além do relato de fatos que muito se assemelham com os do 
período da ditadura civil-militar, o autor faz menções a nomes de personagens que existiram e/ou que ainda existem e que, de certa forma, influenciaram a história política brasileira. É o caso de João Miguel, citado na página 11 e que sugere ser João Miguel Vitaca, figura política, de considerável influência no campo sindicalista. Outro nome referido é o do médico Eduardo Jorge, citado na página 14 que remete a Eduardo Jorge Martins Alves Sobrinho, médico sanitarista, com várias participações políticas no país, sendo, inclusive, candidato à presidência da república em 2014 e a vice-presidente, em 2018. Ainda há a referência aos nomes de Mangabeira (filósofo e teórico social brasileiro), sugere-se Luiz Carlos Cancellier (reitor da Universidade de Santa Catarina), dentre outros.

Por fim, Kucinski, além de tratar de uma perspectiva distópica a respeito do Brasil contemporâneo, aposta, também no hibridismo entre fato e ficção para elaborar em seu romance uma outra "realidade".

\section{REFERÊNCIAS}

BERLIN, Isaiah. Limites da Utopia: Capítulos da História das Idéias. São Paulo: Companhia das Letras: 1991.

BRADBURY, Ray. Fahrenheit 451: a temperatura na qual o livro pega fogo. Tradução Cid Kipnel. São Paulo: Globo, 2020.

BRANDÃO, Ignácio. Desta Terra Nada Vai Sobrar, A Não Ser o Vento que Sopra Sobre Ela. $1^{\text {a }}$ ed. São Paulo: Global: 2018.

BRANDÃO, Ignácio. Não verás país nenhum. 28ª ed. São Paulo: Global: 2019.

BRANDÃO, Ignácio. Zero. 14ª ed. São Paulo: Global: 2019.

CÂNDIDO, Antonio. Literatura e Sociedade. $9^{\text {a }}$ ed. Rio de Janeiro, Ouro sobre azul, 2006.

CLAEYS, Gregory. Dystopia: A Natural History. United Kingdom: Oxford University Press, 2017. 
EAGLETON, Terry. Capitalismo, Modernismo e pós-modernismo. Trad. João Roberto Martins Filho, Revisão Técnica.Tânia Pellegrini. In:Crítica Marxista. São Paulo: IFCH Unicamp, n.1, agosto 1994. p. 53-68

FIGUEIREDO, Eurídice. A literatura como arquivo da ditadura brasileira. $1^{\text {a }}$ ed. Rio de Janeiro, 7 Letras, 2017.

GARRAMUÑO, Florencia. Frutos estranhos - sobre a inespecificidade na estética contemporânea. Tradução de Carlos Nougué. $1^{a}$ ed. Rio de Janeiro, Rocco, 2014.

GENETTE, Gérard. O discurso da narrativa. Tradução: Fernando Cabral Martins. $3^{\text {a }}$ edição. Lisboa: Veja, 1995.

GINZBURG, Jaime. Literatura y política en Bernardo Kucinski. Pleyáde Revista de Humanidades y Ciencias Sociales, v. 24, p. 83-95, 2020. Disponível em: https://scielo.conicyt.cl/pdf/pleyade/n24/0719-3696-Pleyade-24-83.pdf. Acessado em: 13/08/2021.

HOUAISS. Dicionário Houaiss da língua portuguesa. Rio de Janeiro: Objetiva, 2008.

HUXLEY, Aldous. Admirável mundo novo. Tradução Lino Vallandro e Vidal Serrano. São Paulo: Globo, 2014.

JACOBY, Russel. Imagem imperfeita: pensamento utópico para uma época antiutópica. Tradução Carolina Araújo. Rio de Janeiro: Civilização Brasileira, 2007.

KRYSINSKI, V., \& FARIA, Z. de. (2012). Sobre algumas genealogias e formas do hibridismo nas literaturas do século XX - Vladimir Krysinski. Revista Criação \& Crítica, (9), 230-241. https://doi.org/10.11606/issn.1984-1124.v5i9p230-241

KRYSINSKI, Wladimir. Dialéticas da transgressão: o novo e o moderno na literatura doSéculo XX. Tradução de Ignacio Antônio Neis, Michel Peterson e Ricardo Iuri Canko. São Paulo: Perspectiva, 2007.

KUCINSKI, Bernardo. A nova ordem. São Paulo: Alameda Casa Editorial, 2019. 
KUCINSKI, Bernardo. K - Relato de uma busca. São Paulo: Cosac Naify, 2014.

LATOUR, Bruno. Jamais fomos modernos: ensaio de antropologia. Trad. Claudio Irineu da Costa. Rio de Janeiro: Editora 34, 1994

MORE, Thomas. A Utopia. São Paulo: Martin Claret, 2002.

NUNES, Benedito. O tempo na narrativa. $2^{a}$ ed ição. Série Fundamentos. Editora Ática: São Paulo, 1995.

ORWELL, George. 1984. Tradução Alexandre Hubner e Heloisa Jahn. São Paulo: Companhia das Letras, 2009.

PORTELA, Millena PINTO, Maria. Um presente para o futuro: a distopia contemporânea e suas interseções com a experiência pós-moderna. Revista Eletrônica

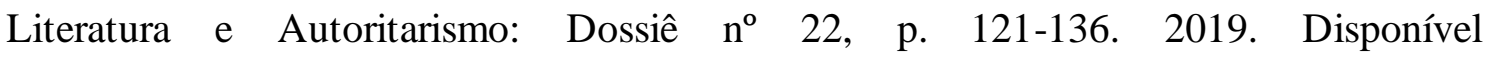
http://dx.doi.org/10.5902/1679849X39202 Acessado em: 15/08/2021. 